\title{
THE COMPARISON OF THE CUMULATIVE GRADE POINT AVERAGE ON MEDICAL STUDENTS LIVING IN DORMITORY AND BOARDING HOUSE OF A MEDICAL SCHOOL
}

\author{
Resiana Karnina \\ Program Studi Pendidikan Dokter, Fakultas Kedokteran dan Kesehatan Universitas Muhammadiyah Jakarta
}

\begin{abstract}
Background: In educational institution, learning achievement is an important indicator to measure the success of the learning process. Academic achievement can be defined as a result of the work that has been achieved by someone in his learning process, which is avoud as a GPA (Grade Point Average) in Higher Education or collage. Many factors that affect the value of GPA one of them comes from external factors ie residence. Medical Program Student of University of Muhammadiyah Jakarta is free to stay in dormitory or boarding house (indekos) during lectures in Faculty of Medicine and Health University of Muhammadiyah Jakarta. The purpose of this research is to determine the comparison and relationship of the Cumulative GPA on Students Living in Dormitory and Boarding House (Indekos) at Medical University of Muhammadiyah Jakarta Class of 2016.

Method: This research uses quantitative analytic research type with cross sectional study. The subject of this research is a Student of Medical Studies at University of Muhammadiyah Jakarta. The Analysis was done by Mann Whitney Test.

Results: There was no correlation between cumulative GPA in Students Living in Dormitory with Indekos with p value 0,292.

Conclusion: There was no correlation between residence's respondent and cumulative grade point of respondents in the research, but with Mann-Whitney test results comparing the rankings between groups, respondents with residence showed that the possibility of cumulative GPA is better than those living in the dormitory.
\end{abstract}

Keywords: cumulative grade point average (GPA), residence, dormitory, boarding house, medical student.

\begin{abstract}
ABSTRAK
Latar belakang: Dalam suatu lembaga pendidikan, prestasi belajar merupakan indikator penting untuk mengukur keberhasilan proses belajar. Prestasi akademik dapat didefinisikan sebagai hasil karya yang telah dicapai oleh seseorang dalam proses belajarnya yang dinyatakan berupa Indeks Prestasi Kumulatif (IPK) pada pendidikan tinggi. Banyak faktor yang memengaruhi nilai Indeks Prestasi Kumulatif (IPK) salah satunya berasal dari faktor eksternal yaitu tempat tinggal. Mahasiswa Program Kedokteran Universitas Muhammadiyah Jakarta bebas memilih untuk tinggal di asrama atau indekos selama menjadi mengikuti perkuliahan di Fakultas Kedokteran dan Kesehatan Universitas Muhammadiyah Jakarta. Tujuan penelitian ini adalah untuk mengetahui perbandingan dan hubungan Nilai Indeks Prestasi Kumulatif pada Mahasiswa yang Tinggal di Asrama dan Indekos pada Prodi Kedokteran Universitas Muhammadiyah Jakarta Angkatan 2016.

Metode: Penelitian ini menggunakan jenis penelitian kuantitatif analitik dengan studi cross sectional. Subjek penelitian ini adalah Mahasiswa Program Studi Kedokteran Universitas Muhammadiyah Jakarta Angkatan 2016. Analisis dilakukan dengan mann whitney.
\end{abstract}

contact: sublime_dr@yahoo.com 
Hasil: Tidak terdapat hubungan antara Nilai Indeks Prestasi Kumulatif pada Mahasiswa yang Tinggal di Asrama dengan Indekos dengan p value 0,292.

Kesimpulan: Tidak terdapat hubungan antara tempat tinggal responden dengan indeks prestasi kumulatif responden pada penelitian, namun dengan hasil analisis uji Mann-Whitney yang membandingkan peringkat antar kelompok, maka responden dengan tempat tinggal indekos menunjukan kemungkinan indeks prestasi kumulatif lebih baik dibandingkan yang bertempat tinggal di asrama.

Kata kunci: indeks prestasi kumulatif (IPK), tempat tinggal, asrama, indekos, mahasiswa kedokteran

\section{PENDAHULUAN}

Dalam suatu lembaga pendidikan, prestasi belajar merupakan indikator penting untuk mengukur keberhasilan proses belajar. Prestasi akademik dapat didefinisikan sebagai hasil karya yang telah dicapai oleh seseorang dalam proses belajarnya yang dinyatakan berupa Indeks Prestasi Kumulatif (IPK) pada pendidikan tinggi. ${ }^{1}$

Mahasiswa yang masuk di perguruan tinggi diberdayakan untuk bergerak menuju mandiri, belajar profesional dan melebihi yang belajar otodidak serta belajar menerima dan memproses informasi dalam berbagai cara. Setiap mahasiswa mempunyai cara belajar yang berbeda-beda. Seorang mahasiswa juga harus mengetahui cara belajar mereka sendiri dan mampu memilih metode atau cara belajar yang sesuai dengan karakter mereka. Mahasiswa akan belajar jika materi yang disampaikan menarik dan mereka menganggap penting materi tersebut. ${ }^{2}$ Salah satunya yang mempengaruhi cara atau gaya belajar mereka adalah tempat tinggal, seperti, Asrama dan Indekos. Selama ini ada beberapa asumsi bahwa mahasiswa yang mengikuti program asrama akan terbentuk sifat yang peka terhadap lingkungan sekitar dan disiplin. Mahasiswa yang tinggal di asrama mudah diajak berkoordinasi, mereka juga bisa lebih berpikir kreatif karena adanya tuntutan kemandirian selama mereka tinggal di asrama. Mahasiswa asrama juga sering mengadakan belajar kelompok antar anak kamar yang tinggal di asrama tersebut. ${ }^{2}$

Mahasiswa yang tidak mengikuti program asrama cenderung tidak peka terhadap lingkungan yang majemuk karena terbiasa hidup tinggal bersama orang tua masing masing atau tinggal secara terpisah di kos/indekos sehingga mereka lebih cenderung susah diajak berkoordinasi dan susah untuk diajak berpikir kreatif. Mahasiswa di indekos lebih sering atau berkeinginan untuk belajar sendiri atau belajar masing masing. ${ }^{2}$

Menurut Anni, ${ }^{3}$ faktor-faktor yang memengaruhi prestasi belajar terbagi menjadi 2, yaitu faktor internal dan faktor eksternal. 1) Faktor internal, yang mencakup aspek fisik, misalnya kesehatan organ tubuh, aspek psikis, misalnya intelektual, emosional, motivasi, dan aspek sosial, misalnya kemampuan bersosialisasi dalam lingkungan. 2) Faktor eksternal, misalnya variasi dan derajat kesulitan materi yang dipelajari, tempat belajar, iklim, suasana lingkungan, budaya belajar masyarakat dan sebagainya. ${ }^{3}$ Sedangkan menurut Nurdin, ada beberapa faktor yang dapat memengaruhi prestasi belajar mahasiswa antara lain: a. Faktor internal, yaitu faktor yang berasal dari dalam diri individu antara lain, 1) Kondisi fisiologi (jasmani). 2) Kondisi psikologis, hal ini meliputi bakat, minat, motivasi, sikap, intelektual mahasiswa. b. Faktor eksternal, yaitu faktor yang berasal dari luar diri individu antara lain, 1) Lingkungan sosial (teman, guru, keluarga, masyarakat). 2) Lingkungan fisik (sekolah, sarana prasana, tempat tinggal: rumah, asrama, kost).

Dalam satu lembaga pendidikan, prestasi belajar merupakan indikator penting untuk mengukur keberhasilan proses belajar mengajar. Akan tetapi, tidak bisa dipungkiri bahwa tinggi rendahnya prestasi mahasiswa banyak dipengaruhi oleh faktorfaktor lain. ${ }^{4}$ Berdasarkan hal tersebut, peneliti 
pribadi ingin mengetahui perbandingan nilai Indeks Prestasi Kumulatif (IPK) mahasiswa yang tinggal di asrama dengan indekos pada mahasiswa Program Studi Pendidikan Dokter Universitas Muhammadiyah Jakarta angkatan 2016.

\section{METODE}

Penelitian ini adalah penelitian kuantitatif analitik dengan metode cross sectional, data yang menyangkut variabel bebas dan variabel terikat akan dikumpulkan dalam waktu yang bersamaan. Penelitian ini dilaksanakan di kampus Cirendeu dan Kampus Cempaka Putih di Prodi Kedokteran Fakultas Kedokteran dan Kesehatan Universitas Muhammadiyah Jakarta. Waktu penelitian ini adalah mulai dari bulan September 2017 sampai November 2017. Teknik pemilihan sampel pada penelitian ini adalah dengan teknik total sampling, yaitu seluruh mahasiswa preklinik Program Studi Kedokteran Angkatan 2016 berjumlah 138 orang di Fakultas Kedokteran dan Kesehatan Universitas Muhammadiyah Jakarta.

Kriteria inklusi dalam penelitian ini yaitu semua angkatan 2016 prodi kedokteran Universitas Muhammadiyah Jakarta, sudah melalui semua blok di semester 1 (satu) dan semester 2 (dua), tinggal di asrama dan indekos, serta bersedia mengikuti penelitian. Sedangkan kriteria eksklusi penelitian ini yaitu mahasiswa yang tinggal bersama orang tua atau pulang pergi (pp), tidak hadir dalam waktu penelitian, tidak mengembalikan kuesioner. Variabel dependen (variabel terikat) dalam penelitian ini yaitu nilai Indeks Prestasi Kumulatif (IPK) dan Variabel independen (variabel bebas) yaitu tempat tinggal mahasiswa.
Pengumpulan data dilakukan untuk mendapatkan data tempat tinggal mahasiswa sebagai variabel independen, dan indeks prestasi mahasiswa sebagai variabel dependen atau variabel terikat. Metode yang digunakan untuk mendapatkan data tempat tinggal mahasiswa adalah menggunakan Kuesioner Identitas, sedangkan data Indeks Prestasi Kumulatif (IPK) diambil dari data akademik Program Studi Kedokteran Universitas Muhammadiyah Jakarta. Data tempat tinggal dikategorikan menjadi mahasiswa dengan tempat tinggal di asrama atau indekos. Data IPK dikategorikan sesuai Permendiknas No. 232 Undang-Undang Tahun 2000 yaitu IPK 2,00 - 2,75: Memuaskan, IPK 2,763,50: Sangat Memuaskan, IPK 3,51 - 4,00: dengan Pujian.

\section{HASIL DAN PEMBAHASAN}

Data penelitian dikumpulkan dengan mengajukan kuesioner kepada 138 mahasiswa PSKd tahun angkatan 2016 Universitas Muhammadiyah Jakarta, dengan melihat indeks prestasi kumulatif terakhir dan status tempat tinggal mahasiswa saat ini. Pengumpulan data selama waktu penelitian, yaitu pada bulan November 2017. Dari total sampling 138 responden, 33 responden mengalami dropout dikarenakan tidak mengisi dengan benar atau masuk kedalam kriteria eksklusi penelitian sehingga didapatkan total 105 responden. Rentang indeks prestasi kumulatif responden terendah adalah 2,12 (1,0\%) dan yang tertinggi adalah 3,52 $(1,0 \%)$ seperti pada Tabel 1 
Tabel 1. Indeks Prestasi Kumulatif Responden (total $\mathbf{n}=105$ )

\begin{tabular}{rrrrrrrrr} 
No & IPK & $\mathbf{n}(\%)$ & No & IPK & $\mathbf{n}(\%)$ & No & IPK & n $(\%)$ \\
1 & 2,12 & $1(1,0)$ & 20 & 2,73 & $1(1,0)$ & 39 & 3,07 & $4(3,8)$ \\
2 & 2,40 & $1(1,0)$ & 21 & 2,74 & $1(1,0)$ & 40 & 3,08 & $1(1,0)$ \\
3 & 2,42 & $1(1,0)$ & 22 & 2,76 & $2(1,9)$ & 41 & 3,09 & $2(1,9)$ \\
4 & 2,44 & $1(1,0)$ & 23 & 2,78 & $1(1,0)$ & 42 & 3,10 & $1(1,0)$ \\
5 & 2,46 & $1(1,0)$ & 24 & 2,79 & $1(1,0)$ & 43 & 3,11 & $3(2,9)$ \\
6 & 2,50 & $5(4,8)$ & 25 & 2,80 & $4(3,8)$ & 44 & 3,15 & $5(4,8)$ \\
7 & 2,52 & $1(1,0)$ & 26 & 2,83 & $5(4,8)$ & 45 & 3,20 & $1(1,0)$ \\
8 & 2,54 & $2(1,9)$ & 27 & 2,85 & $2(1,9)$ & 46 & 3,22 & $2(1,9)$ \\
9 & 2,55 & $1(1,0)$ & 28 & 2,88 & $1(1,0)$ & 47 & 3,24 & $2(1,9)$ \\
10 & 2,58 & $2(1,9)$ & 29 & 2,89 & $1(1,0)$ & 48 & 3,25 & $2(1,9)$ \\
11 & 2,59 & $2(1,9)$ & 30 & 2,90 & $1(1,0)$ & 49 & 3,26 & $1(1,0)$ \\
12 & 2,60 & $1(1,0)$ & 31 & 2,91 & $1(1,0)$ & 50 & 3,33 & $2(1,9)$ \\
13 & 2,61 & $1(1,0)$ & 32 & 2,92 & $1(1,0)$ & 51 & 3,37 & $2(1,9)$ \\
14 & 2,63 & $3(2,9)$ & 33 & 2,93 & $1(1,0)$ & 52 & 3,38 & $1(1,0)$ \\
15 & 2,65 & $1(1,0)$ & 34 & 2,96 & $4(3,8)$ & 53 & 3,40 & $1(1,0)$ \\
16 & 2,67 & $1(1,0)$ & 35 & 2,98 & $3(2,9)$ & 54 & 3,43 & $1(1,0)$ \\
17 & 2,70 & $1(1,0)$ & 36 & 3,00 & $6(5,7)$ & 55 & 3,48 & $1(1,0)$ \\
18 & 2,71 & $1(1,0)$ & 37 & 3,02 & $4(3,8)$ & 56 & 3,50 & $1(1,0)$ \\
19 & 2,72 & $3(2,9)$ & 38 & 3,03 & $1(1,0)$ & 57 & 3,52 & $1(1,0)$ \\
\hline
\end{tabular}

Berdasarkan data pada Tabel 1, didapatkan 73 responden memiliki kategori indeks prestasi kumulatif sangat memuaskan $(69,5 \%), 31$ responden memiliki kategori indeks prestasi kumulatif memuaskan $(29,5 \%)$ dan 1 responden memiliki indeks prestasi kumulatif dengan pujian $(1,0 \%)$. Selain itu, 83 responden bertempat tinggal di asrama saat dilakukan penelitian $(79,0 \%)$, sedangkan 22 responden tinggal indekos $(21,0 \%)$. Data tersebut dapat dilihat pada Tabel 2.

Tabel 2. Klasifikasi Indeks Prestasi Kumulatif dan Distribusi Tempat Tinggal Responden

\begin{tabular}{lcc} 
Variabel & Jumlah & $\begin{array}{c}\text { Persentase } \\
(\%)\end{array}$ \\
IPK & & \\
Memuaskan & 31 & 29,5 \\
Sangat Memuaskan & 73 & 69,5 \\
Dengan Pujian & 1 & 1,0 \\
Tempat Tinggal & & \\
Asrama & 83 & 79,02 \\
Indekos & 22 & 1,0 \\
\hline
\end{tabular}

Tabel 3 dibawah ini menunjukkan responden dengan yang bertempat tinggal indekos memiliki persentase $72,7 \%$ indeks prestasi kumulatif sangat memuaskan, 22,7\% indeks prestasti memuaskan dan 4,5\% memiliki indeks prestasi kumulatif dengan pujian. Hasil analisis menunjukan Dengan nilai $p>0,05$ maka secara statistik tidak terdapat hubungan antara tempat tinggal responden dengan indeks prestasi kumulatif responden pada penelitian, namun dengan hasil analisis uji MannWhitney yang membandingkan peringkat antar kelompok, maka responden dengan tempat tinggal indekos menunjukan kemungkinan indeks prestasi kumulatif lebih baik dibandingkan yang bertempat tinggal di asrama. 
Tabel 3. Hubungan Tempat Tinggal dengan Indeks Prestasi Kumulatif Responden

\begin{tabular}{|c|c|c|c|c|}
\hline \multirow{2}{*}{$\begin{array}{l}\text { Tempat Tinggal } \\
\text { Responden }\end{array}$} & \multicolumn{3}{|c|}{ Indeks Prestasi Kumulatif Responden } & \multirow[b]{2}{*}{ p-value } \\
\hline & $\begin{array}{c}\text { Memuaskan } \\
\text { n (\%) }\end{array}$ & $\begin{array}{c}\text { Sangat Memuaskan } \\
\text { n (\%) }\end{array}$ & $\begin{array}{c}\text { Dengan Pujian } \\
\mathrm{n}(\%)\end{array}$ & \\
\hline $\begin{array}{l}\text { Asrama } \\
\text { Indekos }\end{array}$ & $\begin{array}{l}26(31,3 \%) \\
5(22,7 \%)\end{array}$ & $\begin{array}{l}57(68,7 \%) \\
16(72,7 \%)\end{array}$ & $\begin{array}{l}0(0,0 \%) \\
1(4,5 \%)\end{array}$ & 0,292 \\
\hline
\end{tabular}

IPK yang didapatkan dari responden adalah hasil belajar tahun pertama mahasiswa, yaitu semester 1 dan semester 2 di jenjang pendidikan Fakultas Kedokteran. Tahun pertama di universitas adalah masa transisi yang kritis. Hal ini dikarenakan masa tersebut adalah masa ketika mahasiswa membuat pondasi dengan gigih agar mencapai keberhasilan akademik yang berkelanjutan. IP universitas semester pertama pada tahun pertama adalah salah satu faktor yang paling bertanggung jawab pada kelulusan mahasiswa di perguruan tinggi. Semakin baik penguasaan akademik mahasiswa maka prestasi yang diperoleh pun akan baik pula. Jadi, selama masa perkuliahan mahasiswa berkompetisi dalam memperoleh prestasi akademik sesuai standar acuan IP. 5

Tahun pertama di sebuah perguruan tinggi adalah waktu yang sangat penting untuk membangun pengetahuan dasar, sikap positif, kepercayaan diri, dan komitmen untuk belajar, yang pada nantinya merupakan landasan bagi kesuksesan akademis dan keberhasilan tingkat akademis selanjutnya. Tahun akademik pertama sangat penting bagi mahasiswa kedokteran, karena mereka menghadapi kesulitan yang lebih besar dan lebih banyak tekanan dalam mata pelajaran mereka dan memiliki risiko penarikan (withdrawal symptom) yang lebih tinggi daripada siswa dengan jurusan lainnya. Penelitian sebelumnya tentang prediktor kinerja akademis di fakultas kedokteran terutama berasal dari Amerika Serikat dan Eropa. ${ }^{?}$

Kemampuan akademik mahasiswa merupakan hasil dari beberapa determinan faktor sosial ekonomi, psikologis dan lingkungan, dimana pendapatan keluarga, usia orang tua, pendidikan orang tua, jam belajar per hari dan kehadiran kelas memiliki hubungan positif dengan prestasi akademis mahasiswa. Selanjutnya, mahasiswa yang memiliki kesehatan fisik yang baik adalah seorang akademisi yang baik. Penelitian dari Kampanye untuk Pendidikan Pendidikan Tinggi, Universitas Columbia memberikan bukti kuat mengenai peran kausal bahwa perbedaan kesehatan yang terkait dengan pendidikan bermain dalam pencapaian pendidikan. Ada beberapa bentuk dalam bagaimana perilaku kesehatan siswa terkait dengan kinerja akademis mereka, seperti pola tidur, aktivitas fisik, perilaku makan, dan stres, semuanya mengarah pada hubungan kinerja akademis. Telah ditunjukkan bahwa aktivitas fisik, dan juga diet yang lebih sehat, bermanfaat bagi kognisi, menunjukkan bahwa perilaku kesehatan dapat mempengaruhi kinerja kognitif individu. Untuk beberapa perilaku kesehatan dan perubahan gaya hidup, oleh karena itu, Grade Point Averages (IPK), yang sering digunakan sebagai ukuran kinerja akademis mungkin dipengaruhi oleh perubahan perilaku kesehatan selama tahun pertama di universitas. Penelitian pada mahasiswa menunjukkan asosiasi antara beberapa perilaku kesehatan (aktivitas fisik, gaya hidup, diet) dan prestasi akademik. ${ }^{9}$

Salah satu faktor yang mempengaruhi indeks prestasi yang tinggi adalah motivasi. Motivasi dalam proses belajar sebagaimana dikatakan Hamzah B. Uno, yaitu: menentukan hal-hal yang dapat dijadikan penguat belajar, memperjelas tujuan belajar yang hendak dicapai dan menentukan ketekunan belajar. Selain motivasi, faktor lingkungan yang berpengaruh terhadap prestasi belajar adalah jarak tempat tinggal..$^{10}$

Mobilitas penduduk adalah proses perpindahan penduduk dari satu daerah kedaerah yang lain. Salah satu faktor yang mempengaruhi mobilitas penduduk adalah kondisi lingkungan setempat dimana kondisi lingkungan tersebut juga dapat mempengaruhi proses belajar. Kertamuda mengatakan bahwa 
lingkungan tempat mahasiswa belajar merupakan salah satu faktor yang dapat mendukungnya dalam mencapai prestasi belajar. Joseph menambahkan bahwa lingkungan sangat mempengaruhi kehidupan manusia, teori empirisme yang menyatakan bahwa perkembangan individu dipengaruhi dan ditentukan oleh pengalaman-pengalaman yang diperoleh pengaruh lingkungan sangat besar dalam membawa diri manusia menuju puncak impian yang sukses dimasa yang akan datang. Sehingga lingkungan merupakan salah satu faktor penting dalam menentukkan keberhasilan seseorang. ${ }^{10}$

Hasil analisis menunjukan Dengan nilai $\mathrm{p}>0,05$ maka secara statistik tidak terdapat hubungan antara tempat tinggal responden dengan indeks prestasi kumulatif responden pada penelitian, namun dengan hasil analisis uji Mann-Whitney yang membandingkan peringkat antar kelompok, maka responden dengan tempat tinggal indekos menunjukan kemungkinan indeks prestasi kumulatif lebih baik dibandingkan yang bertempat tinggal di asrama.

Hasil ini sejalan dengan penelitian Sidiq, ${ }^{11}$ dimana ia mengemukakan tidak ada hubungan antara status tempat tinggal mahasiswa dengan prestasi belajar mahasiswa/i Prodi Keperawatan Banda Aceh Poltekkes Kemenkes Aceh semester Ganjil Tahun Akademik 2012/2013. Selain itu, penelitian ini juga sejalan dengan penelitian Yumira Peluang seorang mahasiswa yang tinggal di kost memiliki kecenderungan indeks prestasi kumulatif (IPK>3,310) adalah sebesar 0,295 kali dari mahasiswa yang tingga dengan orang tua. ${ }^{16}$

Akan tetapi, hasil yang bertentangan di sajikan oleh penelitian Idriyani, ${ }^{12}$ dimana pada responden penelitiannya didapatkan nilai signifikan sebesar $0,040(<0,05)$ yang menunjukkan bahwa tempat tinggal mempunyai pengaruh yang signifikan terhadap prestasi belajar. Hal tersebut menunjukkan bahwa perubahan pada tempat tinggal mempunyai pengaruh yang konsisten terhadap prestasi belajar.

Hasil dari Penn State University, ${ }^{13}$ mengungkapkan sisi positif tinggal di asrama (Housing Campus) selain menambah teman, mudah menolong sesama dan tinggal di kampus ini seringkali memiliki prestasi akademik yang lebih tinggi. Siswa yang tinggal di luar kampus hampir dua kali lebih mungkin untuk mendapatkan IPK di bawah 1.0, selain itu, mereka yang tinggal di kampus memiliki IPK rata-rata 0,19 sampai 0,97 poin lebih tinggi dari mereka yang tidak tinggal di kampus. Kemungkinan kemudahan akademis dekat dengan perpustakaan, dekat dengan ruang dosen, mudah membentuk kelompok belajar dan dekat dengan penasihat akademis adalah kemewahan yang didapat oleh orang yang tinggal di kampus.

Berdasarkan penelitian selama 15 tahun di Universitas Missouri, ${ }^{14}$ didapatkan bahwa mahasiswa baru mempunyai tendensi ber-IPK 2,90 jika tinggal di kampus (Campus Housing), dibandingkan dengan yang tidak tinggal di kampus $(2,64)$, menuju tahun pertengahan, mahasiswa yang tinggal di kampus memiliki tendensi IPK rata-rata 3,16 dibandingkan dengan yang tidak tinggal di kampus (2,90), dan pada masa studi tahun akhir, mereka yang tinggal di kampus memiliki perbedaan IPK 3,33:3,13 dengan yang tidak tinggal di kampus.

Berdasarkan penelitian Feby, ${ }^{10}$ tingkat prestasi belajar mahasiswa yang bertempat tinggal dikos mempunyai tingkat prestasi belajar yang sangat tinggi (15\%), prestasi belajar yang tinggi (42\%), prestasi belajar sedang (31\%), prestasi belajar rendah $(8 \%)$ dan prestasi belajar sangat rendah (4\%), sedangkan hasil penelitian motivasi bahwa tingkat motivasi belajar mahasiswa yang bertempat tinggal dikos mempunyai tingkat motivasi belajar yang sangat tinggi (12\%), motivasi belajar yang tinggi (27\%), motivasi belajar rendah (19\%), motivasi belajar sangat rendah (15\%).

Pada mahasiswa tempat tinggal sangat penting sekali karena kenyamanan dan kelengkapan fasilitas sangat mempengaruhi prestasi belajar, apalagi jika mahasiswa jauh dari orang tua atau tinggal di kos tidak ada yang memantau sehingga jika tidak terpantau maka anak tersebut akan merasa bebas dan tidak bisa memanfaatkan waktu untuk belajar. ${ }^{10}$

Pada penelitian hampir lebih dari setengah responden bertempat tinggal diasramadibandingkan di kos 79:21. Seseorang yang tidak tinggal di dekat kampus, harus berkutat dan berpikir bagaimana 
mengarungi jarak tempuh dari tempat tinggalnya menuju kampus. Apalagi, jika memikirkan letak kampus Universitas Muhammadiyah Jakarta Cirendeu di pusat kota perbatasan Jakarta Selatan dan Tangerang Selatan, pembangunan MRT dan LRT serta kemacetan dimana-mana membuat jarak tempuh 10-20 km menjadi berjam-jam.

Sesuai penelitian Sudaryawan, ${ }^{15}$ jarak tempuh dari tempat tinggal menuju kampus merupakan salah satu faktor kecemasan dan stres yang dapat mempengaruhi kinerja akademis mahasiswa kedokteran. Pada penelitian Putra, sekurangkurangnya terdapat 20 mahasiswa yang mengalami gangguan stres pada satu angkatan Fakultas Kedokteran, dengan usia responden terbanyak adalah 18 tahun, 20 tahun dan 22 tahun yang masingmasing berjumlah 4 orang (20\%), sedangkan usia responden terendah adalah 17 tahun dan 23 tahun, yaitu masing-masing sebanyak 1 orang (5\%). Pada penelitiannya juga dikemukakan bahwa mayoritas partisipan tidak mengalami stres dengan prevalensi $60 \%$, sesuai dengan hasil penelitian ini dimana mahasiswa yang tidak mengalami stress mencapai 60,6\%. Stressor bagi mahasiswa bisa bersumber dari kehidupan akademiknya, terutama tuntutan dari ekssternal dan tuntutan dari harapannya sendiri. Tuntutan eksternal bisa berasal dari tugastugas kuliah, beban pelajaran, tuntutan orang tua untuk berhasil di kulianya dan penyesuaian sosial di lingkungan kampusnya. Tuntutan akademik juga termasuk kompetisi perkuliahan dan meningkatnya kompleksitas materi perkuliahan yang semakinlama semakin sulit.

Mahasiswa yang bertempat tinggal di sekitar kampus secara tidak langsung memiliki tingkat kedisiplinan yang tinggi karena jarak tempuh menuju kampus tidaklah jauh. Dan dapat dilihat dari kehadiran, konsentrasi, catatan pelajaran dan partisipasinya di dalam kelas maka dari dimungkinkan sekali mahasiswa yang keberadaannya dekat dengan kampus memiliki prestasi belajar yang lebih baik. Bagi mahasiswa yang bertempat tinggal dikos lebih cenderung banyak relasi atau masukan dari teman-teman sekamar ataupun teman satu kos, meskipun berbeda jurusan. Biasanya satu kamar baik dikost maupun asrama bisa dihuni 2-6 orang dengan fasilitas yang seadanya sehingga belajar bisa dikatakan kurang kondusif karena ramai dan bisa menjadi kendala dalam prestasi belajarnya. ${ }^{10}$

\section{KESIMPULAN}

Kesimpulan dalam penelitian ini yaitu tidak terdapat hubungan antara tempat tinggal responden dengan indeks prestasi kumulatif responden pada penelitian, namun dengan hasil analisis uji MannWhitney yang membandingkan peringkat antar kelompok, maka responden dengan tempat tinggal indekos menunjukan kemungkinan indeks prestasi kumulatif lebih baik dibandingkan yang bertempat tinggal di asrama.

\section{SARAN}

Bagi penelitian selanjutnya, supaya menggunakan variabel lain yang dapat mempengaruhi prestasi belajar seperti kecerdasan, bakat, minat, kemampuan kognitif, kualitas dosen, bobot materi kuliah, metode perkuliahan, faktor internal seperti kecemasan, stres, depresi, faktor eksternal seperti sosio-ekonomi dan faktor keluarga.

\section{DAFTAR PUSTAKA}

1. The Great Schools Partnership. Grade Point Average. The Glosarry Of Education Reform. 2013.

2. Nai Af. Teori Belajar Dan Pembelajaran. Yogyakarta: Cv Budi Utama; 2017.

3. Anni Ct. Psikologi Belajar. Semarang: Upt Unnes Press; 2007.

4. Nurdin S. Model Pembelajaran Yang Memperhatikan Keberagaman Individu Siswa Dalam Kbk. Jakarta: Quantum Teaching; 2005.

5. Daely K, Sinulingga U, Manurung A. Analisis Statistik Faktor-Faktor Yang Mempengaruhi Indeks Prestasi Mahasiswa. Saintia Matemaika. 2013;1(5):483-94.

6. Sembiring Sjr. Karakteristik Mahasiswa Yang Mempengaruhi Indeks Prestasi Mahasiswa Depertemen Matematika Universitas Sumatera Utara. 2016; Available From: Http://Repository. Usu.Ac.Id/Handle/123456789/62887

7. Zhou Yx, Zhao Zt, Li L, Wan Cs, Peng Ch, Yang J, Et Al. Predictors Of First-Year Gpa Of Medical Students: A Longitudinal Study Of 1285 Matriculates In China. Bmc Med Educ. 2014;14(1). 
8. Hildayati M. Penelusuran Faktor-Faktor Yang Mempengaruhi Prestasi Akademik Mahasiswa Semester I Universitas Ibn Khaldun Bogor. 2002; Available From: Http://Repository.Ipb.Ac.Id/ Handle/123456789/21876

9. Almoajel A, Al Zahrani An, Al Otaibi Ms. Health Behaviors Affecting Academic Performance Among University Students In Riyadh, Saudi Arabia: Ksu Female Students As An Example. Australas Med J [Internet]. 2017;10(10):870-8. Available From: Http://Amj.Net.Au/Index.Php/ Amj/Article/View/3104/1592

10. Iffah Ff. Perbedaan Motivasi Dan Prestasi Belajar Antara Mahasiswa Penglaju Dan Mahasiswa Kos Pada Mahasiswa Pendidikan Ips Fakultas Ilmu Tarbiyah Dan Keguruan Uin Syarif Hidayatullah Jakarta. 2017.

11. Sidiq R, Mardhiah A, Kesehatan K, Indonesia R, Kesehatan P, Prodi A, Et Al. Hubungan Status Tempat Tinggal Dengan Prestasi Belajar Mahasiswa / I Prodi Keperawatan Banda Aceh Poltekkes Kemenkes Aceh Semester Ganjil. 2013;1-6. http://www.jurnal.unsyiah.ac.id/INJ/article/ viewFile/1508/1397
12. Indriyani R. Pengaruh Asal Sekolah Dan Tempat Tinggal Terhadap Prestasi Belajar Mahasiswa Prodi Diii Kebidanan Universitas Wiraja Sumenep. Univ Sebel Maret Surakarta. 2014;

13. Penn State University. Does Living On Campus Affect Grades [Internet]. 2017. Available From: Does Living On Campus Affect Grades

14. Missouri State University. Residence Life, Housing And Dining Services. 2017; Available From: Https://Reslife.Missouristate.Edu/Gpas.Htm

15. Sudaryawan N. The Characteristic Feature Of Anxiety Disorders Batch 2015 Student Faculty Of Medicine Against Exam. 2015;

16. Adriani Tampil Y, Hanny Komalig, Yohanis Langi. Analisis Regresi Logistik Untuk Menentukan Faktor-Faktor Yang Mempengaruhi Indeks Prestasi Kumulatif (IPK) Mahasiswa FMIPA Universitas Sam Ratulangi Manado. UNSRAT September 2017. Diunduh pada tanggal 12 Oktober 2018 di https://ejournal.unsrat.ac.id/index.php/decartesian/ article/view/17023/16560 